\title{
SEBASTIÃO: \\ O SANTO DARDEJADO EM TERRAS DE GOIÁS
}

\author{
Anderson Aparecido Gonçalves de Oliveira* \\ Maria Clara Tomaz Machado**
}

RESUMO: O presente trabalho busca a compreensão das experiências dos sujeitos do interior goiano, em especial das áreas rurais afetadas pela UHE Serra do Facão a partir das práticas festivas religiosas tendo como santo homenageado São Sebastião. O foco da análise serão as práticas e saberes rurais perpassando pela religiosidade desses atores como expressão de seus modos de vida para que possamos analisar como esses fatores fazem emergir as relações de cooperação, vínculos identitários, além de suas variadas formas de sociabilidades, aquelas que são marcas culturais bastante significativas e difundidas durante as comemorações, sejam elas devocionais ou não.

PALAVRAS-CHAVE: Práticas festivas. Sociabilidade. Religiosidade.

* Graduação em História pela Faculdade de Ciências Integradas do Pontal, Universidade Federal de Uberlândia (FACIP/UFU). Mestre e doutorando em História Social pelo Programa de Pós-Graduação em História (PPGHIS) da Universidade Federal de Uberlândia (UFU). Supervisor do Programa Institucional de Bolsas de Iniciação à Docência (PIBID), Subprojeto História (Campus Santa Mônica), da Universidade Federal de Uberlândia (UFU).

** Graduação em História pela Universidade Federal de Uberlândia (UFU), mestrado e doutorado em História Social pela Universidade de São Paulo (USP). Professora Titular do Instituto de História (INHIS) da Universidade Federal de Uberlândia, integra a linha História e Cultura, do Programa de Pós-Graduação em História da UFU. Coordena o Laboratório de Pesquisa em Cultura Popular e Vídeo Documentário (DOCPOP). 
ABSTRACT: This study seeks to understand the experiences of subjects goiano interior, especially in rural areas affected by the UHE Serra do Facão from religious festive practices having as honored saint San Sebastian. The analysis of the focus will be rural practices and knowledge permeating the religiosity of these actors as an expression of their way of life so that we can analyze how these factors make emerging cooperative relations, identity links, and its various forms of sociability, those cultural brands very significant and widespread during the celebrations, whether or not devotional.

KEYWORDS: Holiday Practices. Sociability. Religiousness.

[...] ao viver em comunidade ou sociedade, os saberes e culturas que permeiam essas relações são repassadas às gerações seguintes mantendo, de certa maneira, a reprodução da vida em sociedade, garantindo assim o sentido de viver em comunidade. Sentidos os quais são culturais e são compartilhados entre famílias e vizinhanças. (VENÂNCIO, 2008, p. 110).

Muitas das vezes nos levamos por uma interpretação limitada da palavra compartilhar. Na vida rural, esse compartilhar se confunde literalmente com a vida e o vivido de cada sujeito, de cada família, de cada prática festiva ou momentos de dor e sofrimento. Podemos dizer que os sentimentos de vazio e de incerteza foram os mais compartilhados entre os moradores de uma pequena região do sudeste goiano.

Naquele "pedaçinho de terra", inúmeros trabalhadores viram o suor de seu labor diário se perder em uma imensidão de água em nome do progresso. Assistiram suas memórias e vidas afundarem em águas profundas, até que de repente tudo aquilo não passasse de meras lembranças que, quando acessadas, levavam a momentos de lágrimas e emoções indescritíveis.

Durante um período aproximado de vinte e quatro meses de 
realização do "Programa de preservação do patrimônio históricocultural", intitulado Caminhos da memória, caminhos de muitas histórias ${ }^{1}$, uma iniciativa interdisciplinar envolvendo docentes da Universidade Federal de Uberlândia (Campus Pontal - ItuiutabaMG e Campus Santa Mônica - Uberlândia-MG), percorremos vielas e estradas à procura de respostas. No entanto, a cada porteira aberta, éramos bombardeados por inquietações e inconformismo. Nesse lugar, encontramos comunidades repletas de uma riqueza cultural que permeia o mundo rural e com sujeitos que construíam seus vínculos com o lugar, tendo justamente em suas práticas culturais e religiosas o elo revigorante de múltiplos sentimentos, entre eles o de pertencimento.

À medida que caminhávamos pelas "estradas vicinais" que ligavam não só uma propriedade a outra, víamos entrelaçar vidas e histórias, o sertão goiano foi se revelando familiar, instigante e envolvente. Às margens do São Marcos, seja ao som do vento balançando as folhas da vegetação, dos pássaros ouvidos à distância ou ao embalo das águas que iam inundando de incertezas a vida dos moradores, fomos reconstituindo, por meio das vozes daqueles que se faziam presentes, as histórias do lugar, as expectativas, os medos e as angustias de um futuro já presente. E, no agora, os sentimentos fluíam, trazendo do fundo do passado as histórias vividas e ressentidas.

Sentimentos presentes e evidentes que se tornaram marcas na construção do livro e de um filme que revelaram as memórias e as histórias dos sujeitos sociais da região (KATRIB, 2010), ao

1 O estudo se deu entre os anos de 2008 e 2010, nos municípios afetados pela construção da barragem da Usina Hidrelétrica Serra do Facão, em Goiás e Minas Gerais, a saber: Catalão, Campo Alegre de Goiás, Cristalina, Davinópolis e Ipameri, em Goiás; e Paracatu, em Minas Gerais. Das várias ações compensatórias, participamos, dentro do Grupo de Pesquisa, daquela que trata da preservação do patrimônio histórico cultural da área atingida pelo consórcio dessa usina, cujos produtos acadêmicos foram a produção de um livro, de um filme, dos museus abertos, dos relatórios e da organização documental inventariada com banco de dados de imagens, bibliografia, história oral, assim como levantamento de espécies da flora e da fauna. 
passo em que aqueles que até então estavam esquecidos ou marginalizados por uma sociedade que privilegia o progresso desmedido se tornam agentes de sua própria história, rememorando, revivendo e muita das vezes desabafando como se gritassem por socorro. Desta forma, tanto o livro quando o filme se tornaram mais do que resultados de uma pesquisa histórica e cultural, mas também um espaço de reflexão para entendermos as imposições que se aplicam a sujeitos sociais sem o mínimo de sua participação no projeto que se quer progressista, mas de fato é a expulsão premeditada de suas terras. A negociação possível é dada pelo preço de mercado plausível pelos interesses em questão. As transformações sempre irão existir - e devem -, mas a questão é respeitar o seu tempo, levando-se em consideração os sentidos e as relações humanas que nelas se encontram imbricadas.

Para este texto, como interlocutoras do viver em comunidade, elegemos as práticas festivas, devocionais ou não. As práticas festivas nos revelam as transformações e caminhos percorridos por cada família e sujeito durante o período de construção da Usina Hidrelétrica, porque, assim como a cultura, possuem um sentido muito fluido. Elas se fazem bem mais que uma mera comemoração dentro das várias representações culturais, pois falamos de uma prática que entrelaça vivências, experiências, entre muitos outros fatores que se englobam no que chamamos de "festa". Segundo Carlos Rodrigues Brandão, as festas vão além do cotidiano, interpenetram-se na vida humana, tornandose parte dela, pois "cada vez mais a festa não quer tanto se opor à rotina, ao trabalho produtivo, mas sim invadir a política, o lado sério, as relações que entre si os homens trocam." (BRANDÃO, 2010, p. 21).

No interior goiano, esse fator se torna claro na ótica desta análise, principalmente nas áreas rurais, pois uma boa parte dos moradores ainda sobrevive a partir de uma prática agropastoril familiar. Sendo assim, essas práticas festivas se tornam cada vez mais importantes para os sujeitos, para agradecer a boa colheita, pedir chuva em um tempo de seca ou pedir que a produção do ano seguinte seja melhor. 
É neste sentido que a vida compartilhada ganha destaque onde o compartilhar significa viver coletivamente os importantes momentos e as comemorações pessoais. É por isso que as práticas festivas constituem o laço que interliga os moradores de um determinado lugar, estreitam as relações entre as famílias e interrompem as labutas diárias e o "corre-corre" da lida cotidiana. Durante as festas, os sujeitos participam ativamente da organização do evento, das rezas, dos bailes, dos leilões; e, ao frequentar esses espaços, reforçam com a comunidade os laços de amizade, de solidariedade, de sociabilidades e de compromisso com o sagrado, pois a fé, neste caso, compõe uma religiosidade popular que se inova a cada instante sem perder sua matriz "residual". "Residual" porque

certas experiências, significados e valores que não se podem expressar ou verificar substancialmente, em termos da cultura dominante, ainda são vividos e praticados à base do resíduo cultural bem como social - de uma instituição ou formação social e cultural anterior. (WILLIAMS, 1989, p. 125).

Dentre as relações presentes nas práticas festivas, é válido ressaltar ainda a busca incessante pela visibilidade e pela promoção social que se fazem presentes nos eventos, configurando tais práticas ao mesmo tempo como um campo de disputas, sejam elas políticas, econômicas ou sociais. É um "jogo jogado" pelos atores sociais, em que geralmente o discurso distancia-se da prática no mesmo momento em que o papel real se confunde com o construído. São relações que ultrapassam os limites da prática festiva e tornam-se parte do íntimo e pessoal, surgem dentro da festa e passam a ser perceptíveis também fora dela, durante as relações de convivência e trabalho. Na versão de Bataille, "a festa é a fusão da vida humana. Ela é para a coisa e o indivíduo o cadinho onde as distensões se fundem ao calor intenso da vida íntima" (BATAILLE, 1992, p. 74).

Sendo a festa parte intrínseca da vida humana, as relações e emoções constituídas e/ou vividas pelos sujeitos fazem parte de 
um "jogo de sentidos", no qual sentimentos são colocados à prova e os seus diversos participantes no mesmo patamar de igualdade, pois as festas revigoram energias, vidas. Elas proporcionam momentos revigorantes para aqueles que labutam o ano todo pelo seu sustento. As festas são a vida, ou melhor, a alegria de viver! (KATRIB, 2009).

Marta Abreu nos lembra que há um grande risco de trabalharmos com o conceito "religiosidade popular", por considerar que "traz um risco de se reduzir a complexidade do fenômeno religioso, simplificando a análise das relações entre religião e sociedade, religião e classes sociais, e finalmente religião e história" (ABREU, 1994, p. 84). E ainda reconhece que:

As expressões/conceitos cultura popular e religiosidade popular devem ser propostas em função de um reconhecimento evidente que, no passado, as pessoas pobres, simples, comuns, escravos, negros e imigrantes pobres, pensavam, agiam, criavam e transformavam seu próprio mundo (valores, gostos, crenças) e tudo o que lhes era imposto, em função da herança cultural que recebiam e de sua experiência. Como agentes de sua própria história (cultura e religião) homens e mulheres das camadas pobres criam, partilham e se apropriam de valores, hábitos, atitudes, crenças, músicas e festas religiosas (neste sentido, cultura popular e religiosidade popular não são entendidas simplesmente como um conjunto de objetos ou práticas originário dos setores populares). (ABREU, 1994, p. 85).

O fato é que, mesmo sendo uma prática religiosa (re)criada pelos sujeitos e que difere dos ritos institucionais, mantém características e ritos inerentes a esse catolicismo vertical, enfim mantém-se um "residual" intrínseco. Ocorre o que podemos chamar, neste momento, de uma hibridização religiosa a partir de uma multiplicidade de pertencimentos, mas com características e ações reinventadas, principalmente pelos moradores do interior brasileiro. Neste viés, devemos levar em consideração que o catolicismo oficial é muita das vezes apropriado pelos anônimos 
sociais que praticam o chamado catolicismo popular/rústico/ rural, e aí, em vários momentos, os papeis se invertem. Nesta perspectiva, Azzi confirma:

A religião popular enquanto catolicismo rural, herdado do instituto do padroado e da noção de Cristandade, caracteriza-se pela presença marcante dos leigos como estimuladores da vida religiosa (irmandades, romarias, ermidas, devoções, procissões, festas), entrando em conflito com a imposição da romanização, isto é, do catolicismo tridentino, que privilegia a autoridade sacerdotal. (AZZI, 1997, p. 10).

A partir da maneira como esse catolicismo rústico e rural foi se projetando ao longo de séculos no Brasil, percebemos uma lógica própria de devotamento aos diferentes santos católicos se fortalecendo de forma diversa em cada região do país, obedecendo à diversidade étnica e cultural da população (CHAUí, 2007).

Mauro Passos vai além. Para ele, há um caminho natural entre a prática religiosa "tradicional", datada dos primeiros três séculos, perpassando pelo surgimento de formas híbridas. Um momento em que a cultura e a fé se expandem de uma forma "reformada" até algo novo, em que ambas tentam coexistir, seria uma forma "renovada" daquilo que denominamos como práticas religiosas populares (PASSOS, 2002). Ainda, segundo ele, "a fé pode ser lida como uma alternativa para expressar os sentimentos e ativar a memória coletiva", pois:

O catolicismo popular e as tradições populares, com suas diversas formas de expressão festiva, são promessas de comunidade. Correntes que unem os membros de um grupo. Labirintos da saudade. [...] A festa memorada fertiliza os corpos para um coletivo reunificador. Faz brotar o vigo da esperança. Partilha segredos e desejos. Endereça caminhos no horizonte da espera. (PASSOS, 2002, p. 190).

Contudo, devemos tomar cuidado com a forma com que abordamos este assunto, pois: 
Penetrar na esfera da religiosidade popular é, para o historiador acostumado com fontes documentais que atestam transformações, mudanças, andar em terreno movediço. Religiosidade e fé são práticas culturais observáveis, mas situam-se no âmbito da esfera discursiva e não dos resultados. Desse ponto de vista, fé é uma questão de se possuir, não de se provar. A temática não permite possibilidade de análise através do saber científico construído. Não há regras que garantam a produção do fenômeno, sua repetição e verificação. Por isso, cabe a ressalva: se quisermos compreendê-la, há necessidade de se desvencilhar dos modelos oficiais, intelectualizados, que, de cima para baixo, a rotulam como crendices e/ou superstições. (MACHADO, 1998, p. 113-114).

Nessa perspectiva, a religiosidade popular se abre como um campo de investigação privilegiado para aqueles que a entendem como práticas e representações culturais coletivas, presentes nas experiências concretas de vida dos indivíduos e, portanto, parte constitutiva do social, no qual uma teia complexa de relações as inscreve. (MACHADO, 1998, p. 115).

Sendo assim, seria possível desvincular as práticas festivas das práticas religiosas populares? Acreditamos que não, pois estão inseridas em um universo em que Carlos Rodrigues Brandão denomina enquanto "experiência religiosa e/ou experiências simbólicas coletivas", o que permite ressaltar que "a festa invade a vida humana", interpenetra-se na vida, tornando-se parte, fundamental para a manutenção e para o sentido da mesma.

Para analisar tal discussão, podemos trazer neste momento as festividades rurais no entorno do Rio São Marcos, no estado de Goiás, em especial na comunidade rural de Mata Preta, município de Catalão-GO, onde se cultua São Sebastião2 pelos

2 São Sebastião é um santo, cuja trajetória de vida se mistura com a proteção do ser humano e do que o mantém vivo. É considerado por muitos protetor contra pestes, fome e guerra. A devoção ao santo dardejado foi trazida ao Brasil pelos lusos ainda durante o processo de colonização. Para saber mais, consultar Anderson A. G. de Oliveira (2014). 
mais variados motivos ou experiências vividas pelos sujeitos. $O$ apogeu da prática festiva religiosa encontra-se durante a reza - 0 terço cantado -, momento em que as emoções transparecem e cada um demonstra a fé à sua maneira.

$\mathrm{O}$ que pretendemos afirmar é que os moradores do interior goiano, em especial da área pesquisada, possuem, como protagonistas das festas, seus santos devocionais. São Sebastião surge neste caso por ser um dos mais festejados, principalmente pela região possuir como uma das características principais uma economia familiar diretamente ligada à terra. A missa (um rito praticamente fechado sem grandes modificações), rezada pelos padres, nem sempre se torna o ápice desses dias festivos, onde o importante são as práticas recriadas por esses sujeitos - como o terço cantado -, as quais classificamos como religiosidade popular, catolicismo rústico e/ou rural, entre outras nomenclaturas usadas pela academia por se fazerem diferentes da prática dominante (BRANDÃO, 2007).

As festividades em Goiás são expressões dessa pluralidade. No sudeste goiano, o calendário festivo-devocional mantido pelas comunidades transcorre independente da presença oficial do clérigo, pois os rezadores da localidade assumem o papel de interlocutores com o sagrado. São eles que atiçam o reavivar da fé local e unem as pessoas em torno da realização dos festejos.

O destaque que damos a São Sebastião decorre de sua peculiaridade, especialmente sua realização, a princípio, na área rural. Recebe influência direta das Folias de Reis, tendo o mártir como principal intercessor junto a Jesus Cristo. A região de Mata Preta, situada a cerca de vinte quilômetros da área urbana do município de Catalão-GO, recebe todos os anos a peregrinação de fé dos foliões de São Sebastião.

Segundo a memória local, as festividades em relação ao mártir se iniciaram entre os anos de 1950 e 1960, quando ainda eram utilizados carros de boi para o transporte, mas, com o passar dos anos e as modificações promovidas pelo progresso, como a chegada do asfalto, tal meio de transporte foi proibido nas rodovias, as quais cortam grande parte das estradas de 
acesso às fazendas que compõem essa região. A rodovia, que deveria beneficiar a região, tornou-se um marco divisor das comunidades e das famílias devotas a São Sebastião. Este não seria o primeiro obstáculo que a fé e a devoção dos moradores da região enfrentariam. Mas, ao invés de esmorecer diante do problema, terminaram por se adequar com novas formas de deslocamento e acesso às demais fazendas que todos os anos recebiam o santo em suas residências.

Os festejos na região da Mata Preta iniciam-se no fim de semana mais próximo ao dia 20 de janeiro, todos os anos, com o deslocamento dos foliões que moram na cidade para o campo ainda na quinta-feira. Ali, um devoto e/ou devota já os aguarda em sua residência, com uma farta e bela janta. Antes de saciarem a fome, direcionam-se todos para o altar montado geralmente na sala da residência e, ao som dos estouros do foguete, iniciam um admirável e emocionado terço com a presença dos foliões, donos das casas, vizinhos e convidados. Os participantes nos lembram que, nesse momento, antes de tudo, seu compromisso é com São Sebastião. Vários são os pedidos durante o terço, mas o principal deles é que o mártir os ilumine nos dias seguintes durante sua peregrinação de fé. ${ }^{3}$

Antes de se servir a janta, ocorre mais uma pausa, momento de agradecer a refeição e pedir a São Sebastião que multiplique o alimento daquela mesa, para que a família que os recepciona nunca passe dificuldades, e que os livre da peste, da fome e da guerra. E a noite não se encerra por aí. O santo (representado por sua bandeira) dorme na casa em que o jantar foi oferecido, enquanto os foliões se direcionam à casa do festeiro responsável por sua estada ao longo dos dias festivos até a entrega da bandeira.

3 Atualmente, em decorrência das transformações de tal prática, o ritual tem um período de realização de três dias e se aproxima muito da Folia de Reis. Contudo, apesar de possuir uma estrutura básica aos moldes daquela que homenageia os Santos Reis, essa prática se modifica nas letras das ladainhas, que quase sempre entoam pedidos de proteção e/ou pedidos diretamente direcionados aos donos das residências, que por ventura tenham votos para o santo dardejado ou que passaram por algum tipo de flagelo. 
Com o raiar do sol no dia seguinte e o primeiro canto do galo, lá estão todos de pé na casa onde o santo pousara e preparados para seguirem com a folia. Antes de saírem, mais um pedido de proteção, mais uma demonstração de fé. Diferentemente das décadas de 1950 e 1960, quando os foliões se deslocavam em carros de boi, agora eles se agrupam na boleia de caminhões em direção à residência em que São Sebastião pousou. Após um longo e farto café, a folia agradece a estada e segue percorrendo um longo caminho, fazenda após fazenda, louvando e pedindo proteção para as famílias, plantações e animais das casas visitadas. Processo que se repete até à chegada do almoço, onde a cantoria se estende, pedindo para que ali possam se alimentar. Não é uma regra, mas quase sempre o jantar e o almoço servidos aos foliões, assim como para qualquer pessoa que ali quiser se alimentar, é fruto do pagamento de votos ou se faz em atendimento à solicitação do festeiro. Percebe-se que poucas são as alterações nos endereços em que se alimentam todos os anos e, se há alguma regra, ela parece estar ligada à fartura.

Os dias subsequentes, até o domingo, dia da entrega da bandeira, são da mesma forma, percorrendo os caminhos vicinais de muitas histórias de fé e de emoção. Ali, no momento em que o capitão apita e dá início à cantoria, a vida pessoal, em grande parte de pessoas simples, se confunde com a prática festiva, resultando em lágrimas e lembranças principalmente de pessoas que já se foram. Como nos revela Dona Elza:

Uai, primeiramente que a gente é devoto, né? De São Sebastião e que a gente gosta. [...] É igual que cês viu, eu chorei muito, porque meu pai fazia parte de uma folia, né? Toda vez que eu vejo cantar eu emociono, porque eu lembro dele e ele já faleceu. [...] Cunhado folião, sobrinho. Igual meu pai, era doente, mais acompanhou, até falecer ele acompanhava. Então a gente lembra muito dele nesses momento, né? Que toda vez... assim, até no DVD que a gente vai por pra assistir eu quase num gosto de colocar, porque eu lembro. Aí, quando eu vejo cantano, assim, é o mesmo que eu visse ele junto. Então, a gente fica emocionado. Não triste, é porque alembra, 
e a gente emociona, né? Mais aí é muito bonito, a gente gosta muito. Isso faz parte da vida da gente desde de pequeno, né? [...] Na hora que começou a cantar aqui, agora, me marcou muito, porque eu lembrei... reviveu tudo. Pensa tudo. Que... é que... como a gente via ele, né? Cantano, acompanhano... Pra ele, aquilo era tudo, porque ele amava andar assim, gostava demais. [...] Era a paixão dele. Isso era a paixão dele, do meu pai. Deixava tudo que ele tava fazendo pra acompanhar. Quando... quando tinha a folia da região, ele deixava tudo e acompanhava. Mesmo doente, às vezes tinha vez que saía da folia, ia pro hospital, internava, voltava, porque ele tinha o problema, né? Inclusive faleceu por causa disso. E a gente alembra muito!. (Entrevista realizada com Elza Francisca Braga de Souza, região da Mata Preta, Catalão-GO, em janeiro de 2009).

Esse é um fato recorrente, principalmente por se tratar de uma região em que todos se conhecem ou pertencem ao mesmo núcleo familiar. Nesse viés, as histórias de vida e a Folia de São Sebastião tornam-se o elo de ligação, pois, ainda que de modo indireto, todos da comunidade fazem parte dessa prática festiva religiosa, especialmente se levarmos também em consideração que mais de $90 \%$ desses moradores possuem uma prática agropastoril familiar.

Há vários anos consecutivos que o festeiro responsável pela Folia de São Sebastião é o mesmo, o Senhor Cacildo Rodrigues Duarte, pequeno proprietário na região da Mata Preta. Segundo o próprio, ele não realiza a festa por voto ou obrigação, e sim pela devoção que tem a São Sebastião. E é sua filha, Maria Helena, quem geralmente recebe os foliões todas as quintas-feiras que antecedem o início da peregrinação da folia em sua casa, oferecendo-Ihes um farto jantar e um pouso para São Sebastião.

Como festeiro, o Senhor Cacildo tem por obrigação fazer o convite a toda a comunidade e angariar fundos ou doações por meio de alimentos e/ou animais que possam ser utilizados durante o jantar do domingo, após a entrega da bandeira e do terço cantado. Para além disso, cabe a ele também organizar o cronograma de fazendas que irão percorrer por dia e em quais delas será o almoço e o jantar dos foliões. 
Ela começou de voto, com um tal de Geraldim (Geraldo), ele era um coitado [humilde]... Num tinha ela aqui no lugar não... [...] Ele tinha uma doença e ele, acho que ele falou que, se sarasse, se São Sebastião ajudasse que ele sarasse, que ele ia fazer a folia de São Sebastião. Não tinha ela aqui nesse lugar. Aí, ele sarou e fez... Aí, ele pediu um almoço. [...] Aí, eu cheguei no Senhor Geraldim e perguntei que dia que era pra nóis dar o almoço ou a janta. Ele era gago, né? Gaguejou lá e falou: “- É amanhã..." Eu falei: "- É almoço ou janta?" Ele: “-É almoço..." Então, pode espera ocêis? Pode... Aí, quando deu onze hora, eles chegou, o almoço tava pronto. Era poquinha gente, só o terninho mesmo, capaz que não tinha ninguém acompanhano... [Só os folião mesmo - voz de Dona Maria] E o motorista... Eu não conhecia ninguém, a Maria não conhecia... Aí... [...] Gabrielim (Gabriel - Capitão do terno na época) almoço. Pôs doce, eles comeu. Pôs café, eles bebeu. Aí, ele me chamou: "- Vem cá!" Tinha um paiolzim alí, igual esse aqui, só que era lá... "- Vem cá, ocê! Cê vem cá um poquim..." Foi ele e o velho Bastião (Sebastião) que era o velho palhaço... "- Oh, aqui não tem folia não?" Eu falei: " - Não!" " - Ocê vai pegar essa folia pra fazer..." Eu falei: “- Eu?! "- É!” [É, nóis vai passar o ramalhete, que naquele tempo era um gaim de flor - voz de Dona Maria] É, era um galho de flor... Mas eu felei: "- Mas nóis num tem suficiência pra isso não..." Ele falou: "- Cê tem fé?" Falei: "- Tenho!" "- Cê tem devoção com o santo?..." “- Tenho!” Aí, nóis conversô lá um poquim e ele falou: "- Chama a esposa..." Eu chamei a Maria, ela veio, eles falou a mesma coisa... Aí, eu falei: "- Se ocêis vê que nóis é suficiente... nóis faz..." é... Nóis saiu daqui e foi de a pé lá perto daquela venda, do Geraldim, de a pé debaixo de chuva pegar ramalhete... Aí, nóis fez ela e passou pro Divino aqui... Depois, passô pro meu cunhado, que é o Zé, passou pro Juarez, passou pro Ora... Aí... o Leandro Camilo fez... Foi no Aguinaldo, ele enterrou... E óia aqui pr'ocê vê... Ele tomou castigo mais a muié... Aí, ela ficou... é um ano ou dois? [Dois ano - Dona Maria] sem fazer... Aí, o Arvim mais o tio Arcanjo, um barbudo que é meu tio [...], veio cá num dia de serviço... "- Se ocê adivinha o que nóis vei fazê aqui..." Eu falei: "- Passear..." "- Não, meio de semana nóis num passeia." 
Disse eles. Eu falei: “- Não, passeia! A gente passeia quarqué dia na casa do amigo..." Brincano com eles... Aí, Maria arrumou café, deu eles... Eles falou: "-Oh! nóis vei cá conversar com ocê e Dona Maria pra pegar a folia de novo..." "- Mas como?" Aí, eles explicou tudo... "- Ceis vai lá comigo?" "- Vo..." Chegou lá o home falou: “- Não, eu não vou fazer, por causa que condição eu não tenho... Mas eu entrego os trem..." E já merguiou pra dentro pra buscar os trem. Ele (o capitão da folia) falou: "- Não! O senhor vai levar lá na casa dele" [...] É igual aqui, aonde nóis almoçou, aquela outra casa que nóis foi lá, aquele gordo [...] Ele falou assim pra mim... Falou pra Maria que quer fazer ela um ano... É voto, num é Maria? [É - Dona Maria] pois é... é de voto! Eu vou fala pra ele: "-Ocê vai fazer?!" Se ele fala, eu vou... [Se ele for fazer, é só um ano] É... O que eu puder te ajudar, eu te ajudo... E a Maria... O que cê precisar de mim e tiver nos meus arcance, eu te ajudo... Mais, se ocê não for fazer, quinze dia antes cê me devorve ela que eu vô fazer, Deus ajudano... Com os poder de Deus, de São Sebastião e dos meus amigo, eu faço... E outra... Agora, ocê que quer pagar seu voto... cê pode fazer! E ajudou ele no que eu puder... Aí, nóis pega ela de vorta... Aí, enquanto nóis guentar e Deus der força nóis vai fazer e os amigo... [...] Aí, outro que quiser fazer de voto nóis passa pra ele. [Enquanto a gente tive aguentando, né? Porque a gente vai ficano véi, né - Dona Maria]. Aí, ele faz... Aí, ele faz e devorve pra nóis de novo... [Deus ajudano enquanto a gente tivee... - Dona Maria] Morre... Deus ajudano, enquanto nóis puder dá um coicim, nóis num vai deixar ela morrer não... Eu tenho muita devoção com São Sebastião! [...]. (Entrevista realizada com Senhor Cacildo Rodrigues Duarte e Dona Maria Luiza Duarte ${ }^{4}$, em janeiro de 2013).

Como se percebe na fala do próprio Senhor Cacildo, a festa passou pelas mãos de várias pessoas antes de ficar sob sua responsabilidade e de Dona Maria, sua esposa, incumbidos de

4 Senhor Cacildo e Dona Maria são festeiros da Folia de São Sebastião há vários anos e, segundo eles, o voto de realização da festa continuará sempre respeitado por algum morador da região. 
dar continuidade, em decorrência de uma quebra de corrente, momento em que um membro da comunidade enterra a festa, ou seja, não a realiza.

Em 2014, um pedido especial foi feito ao Senhor Cacildo. Anos antes, Roberto havia solicitado um voto para realizar a Folia de São Sebastião por um ano, mas vinha prorrogando o pagamento de tal voto. Em conjunto com sua esposa, Nilda, e a pedido de sua sogra, Dona Maria, irmã do Senhor Cacildo, tornou-se responsável pelas festividades deste ano. Por capricho do destino, Dona Maria veio a falecer ainda no ano de 2013. Tal fato causou uma grande comoção durante o terço e a entrega da bandeira no último dia das andanças da folia, pois, ao soar da sanfona e os acordes do violão, um trecho do canto da folia foi dedicado justamente a Dona Maria, aquela que sempre estava presente de forma ativa e que foi de fundamental importância para o pagamento da promessa de seu genro.

$[\ldots]$

Vou cantar esse versinho (bis)

pra aquela que não está

Vou cantar esse versinho

pra aquela que não está

(retinta)

Ela está junto de Deus (bis)

lá de cima a nos olhar

Ela está junto de Deus

lá de cima a nos olhar

(retinta)

Foi ela quem te ajudou (bis)

agora ajuda a entregar

Foi ela quem te ajudou agora ajuda a entregar

[...] 
Mais uma vez, a emoção toma conta do espaço em forma de lágrimas que escorrem nos rostos de pessoas simples e de fé. Como um estalar de dedos, todos se transformam num todo, numa unidade, onde, mesmo não conhecendo aquele que já se foi, as pessoas partilham da dor daquela família e demonstram seu carinho e respeito, estendendo sua mão amiga ou com um simples silêncio acompanhado de um olhar lacrimejado. Infelizmente não fora apenas a morte de Dona Maria que abalou a região. Desde o ano de 2013, uma série de perdas humanas vem ocorrendo na região, sejam de formas trágicas ou naturais.

Todos os anos, o último almoço é realizado na casa do Senhor Sinoécio e de Dona Mariana. No fim do ano de 2013, essa família foi marcada por uma tragédia, a morte de um de seus netos por afogamento. A princípio, os foliões ficaram apreensivos, sem saber se eles os receberiam, mas, ao ser questionado, o Senhor Sinoécio fez questão da presença dos foliões, reforçando sua devoção e demonstrando a força de sua fé perante o mártir São Sebastião. Durante todas as refeições, o capitão Diogo sempre puxava uma oração, agradecendo o alimento, pedindo fartura e saúde para a família que os recebia, além de louvar a São Sebastião, suplicando pela proteção contra a fome, a peste e a guerra - o que também pode significar dificuldades a serem enfrentadas e combatidas. Nessa ocasião, a oração para a família do Senhor Sinoécio foi especial:

Senhor Sinoécio, Dona Mariana, pra nós é uma alegria estar aqui hoje com a folia de São Sebastião. A gente quer pedir a Deus que abençoe essa casa, abençoe essa família, abençoe esses alimentos que vamos tomar... Pedimos a Deus que dê força, pra família toda. A gente lamenta a perca que vocês tiveram, mas é Deus que dá força, é Deus que dá o consolo pra vocês... Que São Sebastião possa abençoar essa casa, essa família, que nunca falte o pão de cada dia nessa mesa, livrando de toda peste, de todo flagelo, de todo mau e de qualquer perigo... Em nome do Pai, do Filho e do Espírito Santo, Amém... Pai nosso, que estais no céu... [...] Que o Senhor abençoe a nós e os alimentos em nome do Pai, do 
Filho e do Espírito Santo, Amém... Pelos secos e molhados [Deus seja louvado - resposta dos demais foliões]... E a quem preparou [Nosso muito obrigado - resposta dos demais foliões]... Viva a bela mesa [Viva! - resposta dos demais foliões] [...]. (Diogo Gonçalves Rezende, capitão da Folia de São Sebastião. Oração gravada durante o almoço na casa do Senhor Sinoécio, em janeiro de 2014).

Logo após se alimentar, os foliões sempre pegam seus instrumentos e tocam algumas modas, como forma de agradecer a refeição e se divertir. Naquele ano, acanhados, evitaram repetir esse gesto na casa do Senhor Sinoécio, o qual pediu ao capitão que o fizessem, evidenciando mais uma vez a superação e o agradecimento pela presença dos foliões em sua casa. É claro que o clima não foi o mais festivo, mas, ainda que momentaneamente, a dor deu lugar a um belo sorriso no rosto do Senhor Sinoécio, ele que é calejado pela vida e forte pela fé.

Com o passar dos anos, as festas vêm se modificando, se (re)criando dentro de (re)significações religiosas, econômicas, políticas, entre outras, que influenciam diretamente no resultado do que chamamos de festa. Por esta lógica, devemos levar em consideração inúmeros fatores. Entre eles, o papel econômico em relação ao lucro gerado durante os dias festivos; o político, nos referindo à visibilidade popular e à autopromoção dentro da sociedade em que se encontram inseridos; além do caráter organizacional, características constantes e importantes nas práticas festivas.

Partimos do princípio de que há uma divisão clara nas formas de realização e na vivência das práticas festivas. No caso especial da festa de São Sebastião do mundo rural, ela é fruto de uma prática cultural que segue em ritual cuja essência é a religiosidade. Porém, a festa conhece outra performance voltada para o público urbano.

Festas "de" roça designamos aquelas em que as práticas que as envolvem não sofreram uma transformação a ponto de modificar as características tradicionais. Claro que as (re)criações e (re)significações são constantes, pois acabam sendo naturais 
em relação ao tempo vivido. Ou, por outro lado, utilizando-se do bom português, o "de" levaria a pensar em algo característico daquele espaço, daquele lugar, que pertence àquela região ou lugar.

Já as festas "na" roça designamos aquelas em que fatores externos, principalmente urbanos, influenciaram de maneira profunda as transformações da prática, levando-a a perder várias características que denominamos como tradicionais, desde o sentido devocional ao profano. Aqui, ela se apresenta como uma verdadeira válvula de escape da vida corrida dos centros urbanos, uma forma de se distanciar, mesmo que momentaneamente, do trabalho e das cidades, da rotina. É quase uma festa nostálgica. Uma verdadeira reestruturação praticamente geral na prática festiva, onde o "na", neste caso, nos levaria a pensar em uma festa que simplesmente é realizada naquele espaço rural, a roça, banalizando o sentido original das práticas religiosas rurais, principalmente seu caráter devocional, pois agora o ápice da festa é a diversão simplesmente, não a troca e a coexistência da fé e da sociabilidade. Desta forma, o profano supera o sagrado, o que a descaracteriza quanto ao tradicional, nos levando a considerá-la como algo passível de diferentes sentidos, como afirma Mônica Chaves Abdala:

Saberes e práticas cotidianas são, portanto, reapropriados, se tornam trabalhos, meios de ganhar vida, adequando-se às exigências e preceitos institucionalizados no momento contemporâneo. Como parte da dinâmica cultural de nossas sociedades, essas são expressões dos sentidos de continuidade para os atores envolvidos no processo, nas suas diferentes posições como vendedores, consumidores, funcionários de órgãos públicos que apoiam pequenos produtores, aqueles que organizam as festas, os que delas participam e os que as apoiam como agentes culturais ou pesquisadores. Possíveis continuidades nesse turbilhão vertiginoso, verdadeiro caleidoscópio de identidades heteróclitas que são o retrato desse nosso mundo "pós-moderno" [...]. (ABDALA, 2007, p. 107). 
Até o momento em que nos referimos em romper com o cotidiano, as festas "de" e "na" roça praticamente encontram-se em patamar distinto de sentidos. O santo é o mesmo, mas, a partir daí, inúmeros fatores nos levam a colocá-las em lados opostos. $O$ primeiro ponto refere-se à organização. Durante a realização da festa na roça, os festeiros remuneram aqueles que por ventura trabalham nos dias festivos. Há uma área em que são cobradas taxas em dinheiro para a utilização das mesas; por vezes são disponibilizadas pulseirinhas ou listas para permitir a entrada apenas daqueles que possuem o direito adquirido à mesa. Contase, ainda, um número expressivo de pessoas que se deslocam para os salões comunitários, onde sempre, após as missas e/ou terços, o principal foco é a comida, a bebida, a dança, a paquera. E o principal, nesta festa, é o valor arrecadado com a prática festiva. Após retirar todo o custo da festa, apenas uma pequena parte (isso quando acontece) é repassada para a comunidade e para a Igreja. O restante fica a cargo dos próprios festeiros.

Já nas festas "de" roça, o ponto fundamental que se percebe é o espírito de comunhão e partilha, quando todos aqueles que trabalham durante os dias festivos não recebem nada além da gratidão e do sentimento de devolver um pouco do que São Sebastião proporcionou durante o ano todo. Não há separações entre os sujeitos, independentemente de sua condição financeira.

Por vários anos, essas festas coexistiram praticamente no mesmo espaço, sem a real percepção de que as diferenças agora superam suas aproximações. Muitas vezes, os próprios moradores do entorno das comunidades em que as festas são realizadas e pessoas do centro urbano que se deslocam para esses lugares nem se dão conta de que, em alguns momentos, estão em uma festa como outra qualquer, se assim podemos dizer, apenas sendo realizada em uma área rural. Uma verdadeira teatralização: como se, ao colocar uma botina, um chapéu e se deslocar para a roça, as pessoas pudessem romper com o cotidiano e passar a pertencer, mesmo que momentaneamente, àquela vida rural, àquela fé, àquela crença.

Tais modificações drásticas e o aumento considerável do 
lucro festivo na festa "na" roça têm trazido alguns problemas, principalmente em relação à partilha do valor arrecadado durante os dias festivos. As características tradicionais já vinham se perdendo com o tempo, e o valor pago à Igreja por grande parte delas, em função da utilização do nome do santo, era pequeno, pois era proporcional ao tamanho da prática festiva. Com o decorrer do tempo, em paralelo ao aumento do número de frequentadores, o aumento na arrecadação vem como algo natural. Mas o valor repassado para a comunidade e para a Igreja (quando há) ainda vinha se baseando nas primeiras festas, aquelas de pequeno porte.

O lucro e as relações de "promiscuidade", como foram vistas pela Igreja durante as práticas festivas mais modernas ("na" roça) de algumas regiões do interior goiano, em especial da área rural de Catalão, acabaram fazendo com que o clero decidisse pelo fim dessas festas em algumas comunidades ou adotando outra medida. Já que os centros comunitários não possuem ligação com a Igreja, caso decidissem realizar a festa, não poderiam utilizar os nomes dos santos, o que não seria lucrativo, pois, apesar de perder seu caráter tradicional, são os nomes santos que levam grande parte das pessoas a se deslocarem, mesmo não participando sequer das missas e/ou terços lá realizados antes da festa propriamente dita.

A imposição da Igreja para a realização das práticas festivas em tais comunidades a partir do ano de 2014 determinou terminantemente a proibição da venda de bebidas alcoólicas e uma censura nas músicas, que não poderiam apresentar nenhum sinal de "promiscuidade" ou incentivo a situações que conflitassem com os preceitos da Igreja. Levando-se em consideração que o bar é uma das áreas mais lucrativas da festa, poderíamos dizer que as festas "na" roça, em algumas comunidades de Catalão$\mathrm{GO}$, encontram-se, portanto, em crise, o que pode determinar até mesmo seu fim. As (re)criações e a grandiosidade que se tornaram suas marcas acabaram sendo fundamentais tanto para seu sucesso quanto para o decreto de sua extinção.

Contudo, independentemente das maneiras e dos formatos 
em que os cultos e suas práticas festivas em devoção a São Sebastião, Oxossi, santo flechado, mártir Sebastião e tantas outras nomenclaturas são realizadas; se algumas são mais tradicionais que as outras, se se encontram ou não dentro do oficial, todas possuem um grau de importância no campo festivo religioso nacional. São momentos em que o mártir parece estar sempre presente, seja qual for seu formato ou lugar.

Em todos os anos em que a pesquisa foi realizada, durante o ápice das práticas festivas, fosse nas festas de barraquinha logo após a missa, na Folia durante a entrega da bandeira ou na Umbanda ${ }^{5}$, durante a procissão, a chuva se fez presente, como se São Sebastião demonstrasse gratidão pela manifestação de fé. Como se aquelas gotículas fossem lágrimas de emoção pela entrega e pela fé verdadeira encontrada nos olhos de cada uma das pessoas durante seus pedidos de intercessão.

A chuva tão pedida e tão esperada. As plantações agora balançam viçosas com o vento fresco, ainda molhadas pelas gotículas de água que parecem cair milagrosamente do céu como se agradecessem a oportunidade de florescerem belas e fortes. $O$ sorriso de uma criança ao correr pela chuva ou de um adulto ao ver que sua plantação dará bons resultados. A água que parece lavar não somente o chão, mas também a alma.

Na percepção dos crentes, ela, a chuva, é um evento natural e fundamental para a vida humana. De norte a sul do Brasil, São Sebastião se vê mergulhado em expectativas de sujeitos, quase sempre simples, que entregam seus corações e sua fé, pois, em grande parte das regiões, é essa devoção um dos pilares que sustenta a base de sociedades inteiras. Do pequeno ao grande fazendeiro, do urbano ao rural, todos se rendem aos mistérios que ligam o santo flechado e os momentos em que o sol radiante e o céu azul anil - apesar de belos mas que castigam a terra, a

5 A prática festiva em devoção ao santo dardejado não se restringe ao catolicismo, é evidenciado que ela emerge em outras práticas religiosas, como na Umbanda, nos mesmos dias em que os festejos cristãos, mas com práticas diferentes, levando-se em consideração o hibridismo cultural e religioso ali presente. 
plantação e os animais - dão lugar a uma chuva forte de uma hora para outra, uma verdadeira tempestade de esperança.

A folia emociona muito, né, o cantar da folia... Ah, lá em casa, minha mãe, minha mãe foi nascida na região entre Ipameri e Urutaí... Por exemplo, meu avô recebia... Eles morava na fazenda, tinha pouso de folia, janta, forró... Todo ano, meu avô saía com os foliões, tipo guiando os foliões, o resto do dia, né?... Só que, na roça, era a cavalo naquela época, né? Meu avô que levava: - Oh fulano, cê aceita a folia aí? Oh fulano... E levava os folião nos vizim... [...] E aí... Hora que começa a cantar, minha mãe desaba a chorar, minha vó, minhas tias... Ah, falou assim, que a gente... Eu, pra te falar a verdade... eu... eu mesmo, que sou folião assim, é... eu não posso concentrar muito quando eu vejo assim a dona da casa, a pessoa chorando, assim, que a gente parece que entra naquele mundo ali, a gente acaba emocionado... Eu sou bem chorão... [...] Hora que cê canta, que pede a São Sebastião benzer o seu terreiro, vem benzer a sua casa, ele vem te abençoar, vem livrar da peste, da fome, da guerra, do mal contagioso... então, acaba que, tipo assim, vai de encontro com tudo aquilo que é o desejo da família [...]. (Entrevista realizada com Diogo Gonçalves Rezende. em janeiro de 2013).

Percebe-se, pelos depoimentos, que não há espaço para distinções. $\mathrm{O}$ que se percebe em todas as práticas, seja dentro do catolicismo rústico/popular e/ou oficial, seja em práticas da Umbanda, sejam ricos ou pobres, negros ou brancos, todos se sentem agraciados e abraçados pela proteção esbanjada por São Sebastião. O que enobrece ainda mais essas práticas que possuem o santo flechado como protagonista é justamente essa multiplicidade de cultos, pedidos, agradecimentos, devoções, emoções. Seria válido relembrarmos que o mundo é um só, porém repleto de indivíduos múltiplos que se diferem não apenas na forma física ou no sexo, mas principalmente na maneira de pensar e agir.

Mas a quantidade não resume os verdadeiros sentidos partilhados por inúmeras famílias e sujeitos que irrompem o 
dia e a madrugada em nome de uma sociabilidade que parece satisfazer seus anseios. De uma maneira ou de outra, as práticas festivas tradicionais e características do sudeste goiano - salvo as ponderações que outras regiões interioranas do país também se encaixam nesse momento - possuem contradições que teimam em persistir. $E$ felizmente isso ocorre, pois é essa multiplicidade que torna cada uma dessas práticas rica em detalhes e significados que podem ou não ser partilhados.

Durante o universo de possibilidades em que vários foram os caminhos percorridos, pudemos reler as práticas e experiências de sujeitos que vivem em comunidade, obtendo, como elo de ligação, o santo Sebastião. Tornou-se perceptível ainda que o santo dardejado, torna-se tal elo mesclando-se a um processo transformador no qual outros fatores se inserem: o lugar, suas memórias, as experiências vividas e construídas, os valores culturais, políticos e sociais, mas principalmente seus vínculos identitários afetivos, e porque não morais.

O mártir São Sebastião e as práticas festivas que o elegem como protagonista se revelam envolventes. É um santo no plural que emerge da mais profunda e variada forma de devoção e fé. São práticas que, dentro de suas peculiaridades, se interpenetram de uma forma instigante, interligando-se através de sentidos e sentimentos múltiplos. Neste sentido, as práticas festivas são fundamentais do ponto de vista de uma (re)organização social, política, econômica e cultural das comunidades pesquisadas, bem como, ainda, para a manutenção de vínculos afetivos e identitários. A festa vai além, ela entremeia o vivido e o construído. Ela nos transporta para um momento de rememoração, de momentos felizes e também daqueles que se gostaria de esquecer mas não o são e nem devem porque fazem parte de um processo coeso e ao mesmo tempo contraditório, que mescla fé, diversão, emoção, tensão, interesses privados e coletivos, entre outros múltiplos sentidos que os sujeitos atribuem à festa ainda que inconscientemente.

Contudo, sendo construída cotidianamente, quando atentamos aos pontos acima citados, devemos ainda levar em 
consideração que, mesmo momentaneamente e apesar das disputas políticas e/ou pelas buscas de espaço de visibilidade que se percebem implícitas, a festa torna-se um ponto de união. De uma forma ou de outra, o conceito de comunidade que conhecemos hoje perpassa pelas práticas festivas em seus mais variados sentidos, pois são nelas que se perpetuam e se reforçam os vínculos identitários, não apenas com o lugar, mas com tudo aquilo que nele se encontra inserido, e, nesse processo, o sujeito torna-se personagem principal. Para tanto, partilhamos das ideias de Norberto Luiz Guarinello, ao afirmar que a:

Festa é, portanto, sempre uma produção do cotidiano, uma ação coletiva, que se dá num tempo e lugar definidos e especiais, implicando a concentração de afetos e emoções em torno de um objeto que é celebrado e comemorado e cujo produto principal é a simbolização da unidade dos participantes na esfera de uma determinada identidade. Festa é um ponto de confluência das ações sociais cujo fim é a própria reunião ativa de seus participantes. (GUARINELLO, 2001, p. 972).

Uma unidade que coexiste em torno das práticas festivas que reforçam os laços de amizade e compadrio, tornando ainda mais difícil separar a vida particular da festiva desses sujeitos. A festa, bem como a sociedade em que está inserida, pretende continuar a se (re)construir a partir de influências internas e externas, renovando-se e (re)criando-se.

Nenhuma festa é igual, da mesma forma que nenhum sujeito é. A festa não é perfeita, da mesma forma que o mundo e as pessoas que nele vivem também não são. Mas podemos afirmar que existe uma sensação de perfeição das relações humanas que surgem em meio às próprias imperfeições das práticas e dos homens que as cercam, pois, nelas (as práticas festivas), deixamos transparecer todos os nossos sentimentos que afloram naqueles três, seis, nove dias. E, da mesma forma que a festa precisa de público, nós também necessitamos dela, como se fizesse parte do que somos ou nos tornamos. Devocionais ou não. 
Sagradas ou profanas. Elas se fazem valer dentro do processo transformador de uma sociedade ou região. Transformam-se na ruptura e ao mesmo tempo na junção do antigo com o novo, do que já foi com o que ainda está por vir. Estão aqui e acolá. Estão onde todos nós estamos.

De Norte a Sul, de Leste a Oeste, dos Encantados aos terreiros de Umbanda, o Brasil é cortado por São Sebastião. O que torna o sudeste goiano especial em relação às práticas festivas religiosas em louvor ao mártir é a forma e a capacidade de se (re)criarem diante das mais variadas adversidades. Além de se tornarem um espaço de resistência e permanência de tradições, mesmo com as influências da modernidade. Existem inúmeras formas de se demonstrar as pluralidades de sentidos e possibilidades que envolvem as festas em louvor a São Sebastião, e esta é apenas mais uma. Assemelho, então, esta pesquisa aos caminhos vicinais percorridos pelos foliões durante a peregrinação de fé em louvor a São Sebastião. Caminhos vicinais de histórias múltiplas e envolventes. Estradas que desembocam no inesperado. Uma verdadeira aventura ao percorrer caminhos sem destino certo, apenas seguindo os rastros de muitas memórias.

Todavia, existe uma realidade concreta para as pessoas que vivem nesta região de Goiás e que foram desterradas de seu lugar de origem. A maior parte delas, de posse de suas indenizações, se viram obrigadas a mudar para outras cidades, comprar pedaços de terras distantes de onde viviam, buscar novas formas de trabalho sem a necessária qualificação profissional. Muitos vínculos se perderam, o sentimento de incerteza é enorme. Vizinhos de gerações já não existem. Muitos afirmam que se sentem solitários, desamparados, mesmo que em casas ou terras novas.

Fica aqui uma esperança de que as festas devocionais, tais como a de São Sebastião, resistam a esse impacto social. Sabemos que algumas iniciativas nesse sentido têm sido buscadas. É preciso dar tempo ao tempo para que novos vínculos, formas de compartilhar a fé, a ideia do coletivo e de comunidade se reconstruam, mesmo que de maneiras diversas, posto que no processo histórico os sujeitos sociais são capazes de transformar suas vidas. 


\section{Referências}

ABDALA, Mônica Chaves. Sabores da cultura popular: tradições e mudanças. In.: MACHADO, Maria Clara Tomaz; ABDALA, Mônica Chaves (Orgs.). Caleidoscópio de saberes e práticas culturais: catálogo de produção cultural do Triangulo Mineiro e Alto Paranaíba. Uberlândia: Edufu, 2007.

ABREU, Marta. Festas religiosas no Rio de Janeiro: perspectivas de controle e tolerância no século XIX. Estudos Históricos, Rio de Janeiro, v. 7, n.14, 1994.

AZZI, Riolando. Catolicismo popular e autoridade eclesiástica na evolução histórica do Brasil. Religião e Sociedade, Rio de Janeiro, n. 1, p. 125-149, 1977.

BATAILLE, Georges. A experiência interior. São Paulo: Ática, 1992.

. Teoria da Religião. São Paulo: Ática, 1993.

BRANDÃO, Carlos Rodrigues. Prece e folia: festa e romaria. Aparecida, SP: Ideias e Letras, 2010.

. Os deuses do povo: um estudo sobre a religião popular. 3. ed. Uberândia: EDUFU, 2007.

CHAUI, Marilena. Cultura e democracia: o discurso competente e outras falas. São Paulo: Cortez, 2007.

VENÂNCIO, Marcelo. Território de esperança: tramas territoriais da agricultura familiar na comunidade rural São Domingos no município de Catalão (GO). 2008. 178 f. Dissertação (Mestrado em Geografia) Instituto de Geografia, Universidade Federal de Uberlândia, Uberlândia, 2008.

GUARINELLO, Norberto Luiz. Festa, trabalho e cotidiano. In.: JANCSÓ, István; KANTOR, Iris (Orgs.). Festa: cultura e sociabilidade na América Portuguesa. São Paulo: Hucitec, 2001.

KATRIB, Cairo Mohamad Ibrahim; MACHADO, Maria Clara Tomaz; ABDALA, Mônica Chaves (Orgs.). São Marcos do Sertão Goiano: Cidades, memória e cultura. Uberlândia: EDUFU, 2010. 
ABDALA, Mônica Chaves (Orgs.). Nos mistérios do Rosário: As múltiplas vivencias da festa em louvou a Nossa Senhora do Rosário (1936- 2003). 2004. Dissertação (Mestrado em História Social) - Instituto de História, Universidade Federal de Uberlândia, Uberlândia, 2004.

Foi assim que me contaram: Recriação dos sentidos do sagrado e do profano do Congado na festa de Nossa Senhora do Rosário (Catalão- 1940-2003). 2009. 257 f. Tese (Doutorado em História) Programa de Pós-Graduação em História, Universidade de Brasília, Brasília, 2009.

LIMA, Lana Lage da Gama; HONORATO, Cezar Teixeira; CIRIBELLI, Marilda Corrêa; SILVA, Francisco, Carlos Teixeira da Silva (Orgs.) História e religião. VII Encontro Regional de História. Núcleo Rio de Janeiro. Rio de Janeiro: FAPERJ; Mauad, 2002.

MACHADO, Maria Clara Tomaz. Religiosidade no cotidiano popular mineiro: crenças e festas como linguagens subversivas. História \& Perspectivas, Uberlândia, n. 22, jan./jun. 2000.

. O amálgama da crença no cotidiano popular mineiro: a fé e o festar. RHEMA, Juiz de Fora, v.4, n. 16, 1998.

OLIVEIRA, Anderson A. G. de. Lá vem chegando São Sebastião, vem aqui te visitar: festas, andanças e folias no interior goiano (1960/2014). 2014. Dissertação (Mestrado em História Social) - Programa de PósGraduação em História, Universidade Federal de Uberlândia, Uberlândia, 2014.

PASSOS, Mauro. A festa na vida: significado e imagens. Petrópolis-RJ: Vozes, 2002.

POEL, Francisco Van der (Frei Chico). Os homens da dança: Religiosidade popular e catequese. São Paulo: Paulinas, 1986.

SILVA, Raquel Marta da Silva. Chico Xavier: Imaginário religioso e representações simbólicas no interior das gerais. Uberaba, 1959/2001. 2002. Dissertação (Mestrado em História Social) - Instituto de História, Universidade Federal de Uberlândia, Uberlândia, 2002. 
WILLIAMS, Raymond. O campo e a cidade: na história e na literatura. São Paulo: Companhia das Letras, 1989.

Recebido em abril de 2016.

Aprovado em outubro de 2016. 